Article

\title{
Building Leadership Competencies for the SDGs through Community/University Experiential Learning
}

\author{
Atinuke Chineme ${ }^{1}$, Irene Herremans ${ }^{1, *}$, Stace Wills ${ }^{2}$ \\ 1 University of Calgary, 2500 University Dr. NW, Calgary, AB T2N 1N4, Canada \\ 2 The Strongest Oak Foundation, 61 Valley Woods Way NW, Calgary, AB T3B 6A2, \\ Canada \\ * Correspondence: Irene Herremans, \\ Email: irene.herremans@haskayne.ucalgary.ca; Tel.: +1-403-220-8320.
}

\begin{abstract}
This research provides a case study of how experiential learning opportunities provided by a Master of Science program in Sustainable Energy Development (SEDV) helped to achieve four Sustainable Development Goals (SDG) in a developing country via the partnering goal. It illustrates how drawing on the complementary characteristics of existing educational principles led to the development of a framework that built competent leaders in sustainability. Concurrently, the related experiential learning project realized economic growth, improved the quality of life and minimized the impact to the environment. We analyze the achievement of sustainability leadership and learning competencies of the students involved in a project that incorporates the SDGs under the umbrella of experiential learning theory and the four different knowledge domains necessary to achieve sustainability: declarative, procedural, effectiveness, and social. To effect change, the University of Calgary partnered with community organizations in both developed and developing countries to provide a solar Power Hub in a remote area of Burkina Faso, Africa, called Pâ Village. The Hub's clean energy allowed a women's cooperative to move from manual labour to the mechanical grinding of shea nuts in the manufacture of cosmetics and toiletries. Using a qualitative storytelling and theory-seeking approach coupled with semistructured interviews of the student researchers (focus group discussion), this case study demonstrates how a framework of experiential learning coupled with the different knowledge domains produced change agents in a group of SEDV students. Several general principles are derived from the case study for other educators to use in similar educational applications.
\end{abstract}

\section{G Open Access}

Received: 29 June 2019

Accepted: 10 October 2019

Published: 12 October 2019

Copyright $@ 2019$ by the author(s). Licensee Hapres, London, United Kingdom. This is an open access article distributed under the terms and conditions of Creative Commons Attribution 4.0 International License.
KEYWORDS: experiential learning; SDGs; Burkina Faso; leadership qualities; learning competencies; interdisciplinary; graduate program; community; solar milling; containerized solar generators 


\section{INTRODUCTION}

The concept of sustainability requires a systems-based approach that recognizes interactions among the pillars of sustainability (economic, environmental, and social). This comprehensive approach is required to understand and solve the global challenges of poverty, climate change, loss of biodiversity, urban sprawl, and water scarcity. These challenges are interrelated in complex ways and therefore require solutions generated by the integration of multiple specializations, subjects, and disciplines [1,2]. To solve our sustainability problems, we need to use knowledge to derive solutions that protect the environment while strengthening communities and promoting prosperity [3]. The authors of this case study cover the three pillars by providing a student perspective on how knowledge was used to independently, as well as collectively, derive renewable energy solutions that strengthened a community by economically benefiting a 100-member women's cooperative. The United Nations' vision of the Sustainable Development Goals (SDGs) transforming global development despite sustainability challenges [4] inspired the authors to use the goals as a measure of success. The SDGs strengthen collective action [5] which is an impetus for interdisciplinary knowledge sharing.

The aim of this paper is to provide evidence that an interdisciplinary, experiential approach will help achieve the SDGs and, at the same time, develop leadership and learning competencies when universities work in partnership with non-government organizations (NGOs) and industry advisors. We answer the following question:

How can graduate research projects, which allow for diverse experiential learning, lead to SDG transformative action, develop learning competencies, and build leadership qualities through university, NGO, and industry partnerships?

There is a consensus that the traditional form of education does not lead to transformative action regarding sustainability, and this is attributable to curriculums designed on the assumption that knowledge automatically triggers action [6]. Time and again, the assumption of knowledge causing action has been proven wrong.

In a Learning Revolution article, Orr [7] contributed to the growing concern with traditional learning with the following comment:

“...the way learning occurs is as important as the content of particular courses. Process is important for learning. Courses taught as lecture courses tend to induce passivity. Indoor classes create the illusion that learning only occurs inside four walls isolated from what students call without apparent irony the 'real world'" [7].

Therefore, new methods are required in the "pursuit of knowledge and innovation" [8]. Real-world solutions need to be derived by confronting practical problems and applying the derived solutions in the real-world 
setting. New methods of inspiring learning have ranged from integrating behavioural sciences into educational methodologies [6] to focusing on the student experience as central to learning [9] or the application of sustainability research [10]. The concept of these learning practices is varied and include the transformation of teacher and learner to a deeper understanding of themselves and their learning styles (experiential learning); an understanding of sustainability practices that lead to transformative action (knowledge domains and education for sustainability); and to fostering sustainability leadership qualities (key competencies in sustainability). These concepts were instrumental for the researchers to develop a framework to conceptualize the learning that took place through the capstone research projects of a group of graduate students in the Sustainable Energy Development Master of Science (SEDV) program at the University of Calgary.

Therefore, to investigate our research question, an empirical case study approach was adopted using the authors' observations, induction, and testing with consultation of the project's co-researchers in a semi-formal focus group discussion.

"A case study can be helpful when we are eager to answer the questions of 'how' and 'why', when we cannot influence the behaviour of those involved in a study, and when we want to cover contextual conditions because we believe they are relevant to the phenomenon under study or when the boundaries between the phenomenon and context are not clear" ([11], p. 42).

Using the empirical case study approach, we answer the "how" by analyzing attitudes and conceptions of the students involved in the SEDV research project. Participants provided answers that reflect the significant progress made in achieving the SDGs when experiential learning models and principles are merged with distinct knowledge domains.

Because multiple parties were involved in the SDG project and experiential learning, we begin with background information on each of the major groups and the roles that they played. We then provide the theoretical framework in which the research is set. This is followed by a more thorough discussion of our methods and findings. Finally, we conclude by providing implications for others interested in achieving the SDGs through experiential learning.

\section{CASE STUDY CONTEXT}

The case study context has four sections. The first section provides background on the university program in which the experiential learning project took place. The second section introduces the NGO, The Strongest Oak Foundation (TSO), that brought the project forward to the university program. The third section presents further details on the Burkina Faso Power Hub project and its location. The final section discusses the SDGs that the project targeted. 


\section{Sustainable Energy Development Program}

The Sustainable Energy Development (SEDV) program is a sixteen (16)month graduate program with an interdisciplinary approach to learning. Four (4) academic faculties participate in the learner's educational experience to provide the rare but essential, extensive knowledge required to move forward with more sustainable actions. The faculties include the Haskayne School of Business; the School of Architecture, Planning and Landscape (formerly Environmental Design); Faculty of Law; and the Schulich School of Engineering. The program is a combination of "specialized knowledge with comprehensive and systemic thinking” [1]. Experiential learning principles are applied in the learner's capstone research project: a mandatory program requirement. The Burkina Faso case study is one of such projects.

The research projects are mandated to have the following requirements:

1. Be interdisciplinary in scope;

2. Have a minimum of three dimensions of focus; and

3. Feature energy and environment as two of the dimensions of study.

Students independently choose their research topics as well as potential partner organizations. Nonetheless, to assist students who find it difficult to settle on a research topic, the course instructor invites industry representatives to pitch their projects to the students. This approach is most effective in getting stakeholders to take ownership of sustainability challenges [10], and it enabled a non-profit organization named The Strongest Oak Foundation (TSO) to present its sustainability challenge in the form of the "Solar Village of the Future" concept to the SEDV students. Seven students either volunteered to support the project or carve out an aspect of the project as a research topic. The original "Solar Village of the Future” concept metamorphized into a solar energy project, called the Power Hub, that would create income for a women's cooperative and a community in rural Burkina Faso.

The learning framework adopted by the SEDV program and research course is based on the University of Calgary's foundational competencies, and is in agreement with the concept that "new models of interdisciplinary education promote student teamwork in a shift toward transformative, experiential, and collaborative learning" [11,12]. The University of Calgary's foundational competencies were initially developed by the Office of Sustainability and approved by the University's major governing bodies:

1. Anticipatory thinking and long-term foresightedness;

2. Empathy and understanding of different worldviews and relationships;

3. Capacities for stakeholder engagement and group collaboration;

4. Action-oriented leadership skills and change agency skills; 
5. Critical thinking and decision-making capacity within complexity; and 6. Systems thinking and an understanding of connectedness ([13], p. 33).

The framework was developed from, and is consistent with, prior research that investigated sustainability competencies both for university students and workplace employees [14]. Even though researchers disagree on the necessity for some of the specific competencies, these competencies were agreed to be most appropriate for the University's operations and its educational programs (See Ploum et al. 2018 [14] for a full discussion of these frameworks).

\section{The Strongest Oak Foundation (TSO: The NGO Partner)}

TSO has successfully implemented projects in Burkina Faso for over 12 years. During this time TSO provided renewable energy for illumination to schools and the residences of teachers in five remote villages. Following this success and in consultation with local partners, the concept of electrification for revenue generation was birthed. The idea was to use renewable energy to stimulate commercial activity and capital flow. The project was themed the "Solar Village of the Future".

The project goal was to launch a modular, solar-powered energy center for trade and commerce, called the Power Hub in Pâ Village, Burkina Faso. The Power Hub would provide renewable energy to create local wealth and new job opportunities that meet the needs of the surrounding community" ([15], p.2). In partnership with the University of Calgary's SEDV program and the University of Ouagadougou, TSO wanted to design a facility that would provide renewable energy for trade and commerce. With the help of the students in the SEDV program, proposed activities for the Power Hub included shea nut milling, grain milling, Wi-Fi services, a café, office services (photocopying, printing etc.), solar lantern sales, and cellphone charging services. The facility was intended to ameliorate the work-life of women in the community particularly those involved in the Sougrinooma Women's Cooperative. Prior to the development of the project, the women in the cooperative conducted business manually; the shea nuts were ground by hand. See Figure 1 below. 


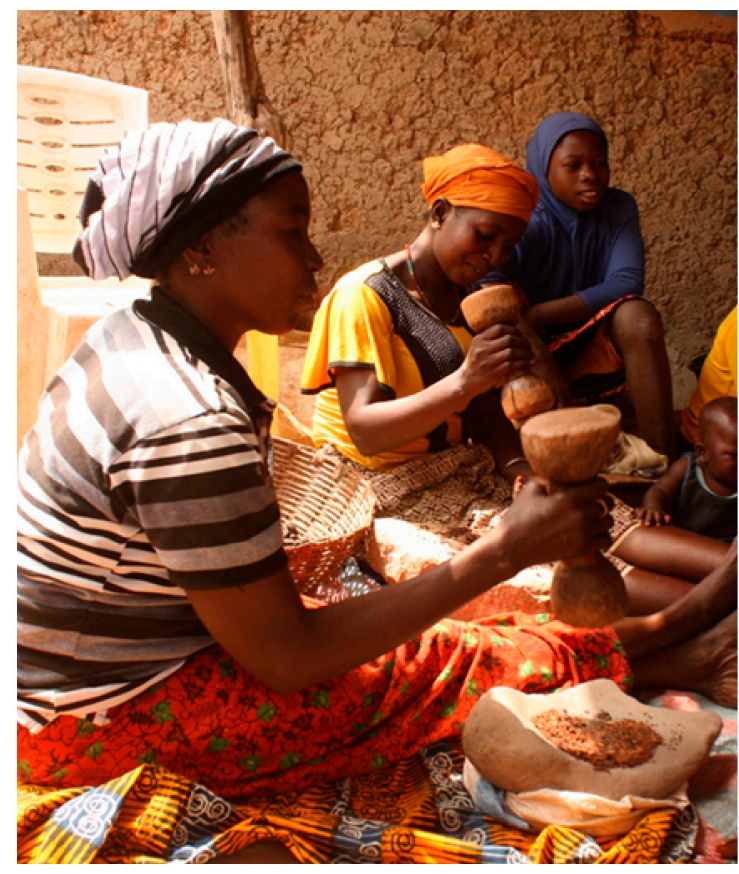

Figure 1. The Sougrinooma Women's Cooperative grinding shea nuts prior to the construction of the Power Hub.

\section{The Burkina Faso Power Hub}

The Power Hub would be a remotely monitored containerized renewable energy and women's economic empowerment project. The proposed solar powered multifunctional platform would provide electricity for light industrial and retail applications like shea nut milling, multi-grain milling, office and café services, phone recharge, and Wi-Fi access [16]. Four facets of the Power Hub were researched and analyzed through capstone projects, thereby enabling students to have a hands-on, experiential learning experience.

The areas of research included the following:

- needs assessment;

- technological feasibility;

- energy demand and supply; and

- financial investment and return.

Together the research studies established ways of making the Power Hub technologically feasible at a reasonable cost of investment, relevant to the beneficiaries and increasing their quality of life while creating as little impact to the environment as possible. Due to the course requirements, each analysis was anchored in energy, the environment, and the economic feasibility of the project. A needs assessment analysis provided evidence that the Power Hub met the needs and expectations of the local community and fit within their norms, culture, and beliefs. The Hub also had to be economically feasible, providing sufficient income to pay back the initial investment and allow for reinvestment of part of the profits for expansion and future growth. This approach enabled learning 
to move across all four knowledge domains: declarative, procedural, impact/effectiveness, and social [6]. Declarative knowledge helps to understand how certain elements work but is insufficient to achieve change. Therefore, a move beyond declarative knowledge to procedural knowledge is necessary for implementing change. As well, each participant assesses his/her effectiveness or impact within the social context or set of beliefs, norms, and biases that exist.

The project was the collaboration of multiple players, in various disciplines, industries, and countries. The Calgary-based non-profit organization, TSO, partnered with the University of Calgary (staff, professors, and students of the SEDV program) and other local and international collaborators like the University of Ouagadougou (Department of Physics, Laboratory of Physics and Chemistry of the Environment (LPCE)), l'Association Monde Meilleur (AMM), Solar Milling, Schneider Electric Foundation, and several other organizations and individuals [17]. The collaboration enabled the application of some experiential learning principles such as the creation of a space for conversational learning, inside-out learning, development of expertise, and learners taking charge of their learning [7], while also achieving the project objectives and contributing to the furtherance of the United Nations SDGs.

\section{The Sustainable Development Goals: Our Criterion}

The United Nations (UN) 2030 Agenda for Sustainable Development provided a blueprint for achieving sustainability by using assigned targets and indicators for the seventeen (17) SDGs. The goals were developed to "stimulate action" due to the urgent and persistent global sustainability challenges [18]. The Burkina Faso case study worked towards contributing to Goal 7 (Affordable and Clean Energy), Goal 8 (Decent Work and Economic Growth), Goal 9 (Industry, Innovation and Infrastructure), and Goal 17 (Partnerships for the Goals). Target 4.7 of Goal 4 (Quality Education), "ensure that all learners acquire the knowledge and skills needed to promote sustainable development..." [18], was more "research student" acquired than a project contribution. By partnering with local and international organizations in diverse sectors, the SEDV students could more fully accomplish these targets.

\section{THEORETICAL FRAMEWORK}

There is general agreement in prior literature that sustainability competencies need to be developed both in university students and in workplace employees. However, there is incomplete agreement that all of the suggested competencies are separate constructs and that they are equally important ([19], p. 399). The degree of importance depends on the objective of the study and the position of the person studied ([20], p. 134). Those competencies recognized as important in all studies are strategy, systems thinking, and interpersonal ([21], p. 350). Those competencies important in some studies, but not all, are anticipatory, normative, action, 
and diversity/interdisciplinarity [14,22]. The significance of the latter set depends on the targeted entity of study, the maturity of knowledge, and other contingent factors [14]. We have retained all competencies for this study as they are consistent with the University's institutional sustainability learning framework.

The educational context best suited for competency development is a situation that allows for integration of knowledge, skills attitudes [23], and behaviors [24]. Salgado et al. 2018 [23] also suggested that this integration occurs best in projects, cases, and problems that provide opportunities for independent learning. We argue that if different knowledge domains occur in an experiential learning setting it provides additional assurance that students will be able to translate diverse shareholder needs and desires into actions toward sustainability [16]. Our work builds on the efforts of Erin Redman which demonstrates that, "even programs focused solely on cognitive outcomes can achieve higher order learning through novel education approaches that engage diverse domains of knowledge" ([25], p. 5). This setting arranges for connecting lived experiences obtained through experiential learning with scientific knowledge obtained through the knowledge domains.

\section{The Experiential Learning and Knowledge Domain Connection}

Experiential learning theory is "a holistic theory that defines learning as the major process of human adaptation involving the whole person" ([9], p. 43). Therefore, behavioural change is a logical expectation from every learner that undergoes an experiential learning process. However, to ensure that knowledge and learning leads to advancement in the environmental pillar of sustainability, it is necessary that "different forms of knowledge must work together in a convergent manner if they are to foster ecological behaviour" [26]. Therefore, the use of experiential learning and the different knowledge domains would change the learner while also advancing sustainability. The knowledge domains required in the process act in the following manner:

"provide an overarching framework for synthesizing various schools of thought in the behavioral sciences, especially in linking predictors of behavior to effective educational approaches for sustainability" ([6], p. 3).

The motivation of the experiential learning and knowledge type framework is to enable change which is driven by deliberate steps taken by leaders educated in sustainability. The adaptation of the experiential learning theory in the framework is based on the consensus of the impact of experiential learning in educating leaders on sustainability. Chief executives and senior leaders demonstrated their support for experiential learning in a survey study by Ashridge Business School and the Academy of Business and Society (EABIS) for the United Nations Principles for Responsible Management Education (UN PRME). 
"The Ashridge-EABIS study for the UN PRME found that 70 per cent of respondents believed that experiential learning was an important element of the learning process for developing the mindsets and skills needed for a changing business context” ([27], p. 300).

The experiential learning cycle is a "holistic model...that encompasses more specialized models of the adaptive process" ([9], p. 50). The specialized models used in assessing the connection between the knowledge domains while evaluating the influence of experiential learning in contributing to achievement of the SDGs include the following:

1. Modes of experiential learning;

2. Experiential learning problem-solving process model; and

3. Principles for the promotion of experiential learning in education.

To link the models, the students' learning experience (the thinking, reflecting, acting, and experiencing model) was also assigned a corresponding knowledge type (declarative, procedural, effectiveness, and social). Figure 2, developed by the authors based on the work of Kolb \& Kolb [9] and Frisk \& Larson [6], illustrates the harmonious relationship between the knowledge domains and where they best fit at specific phases of the experiential learning cycle to develop the sustainability competencies required for achieving the SDGs.

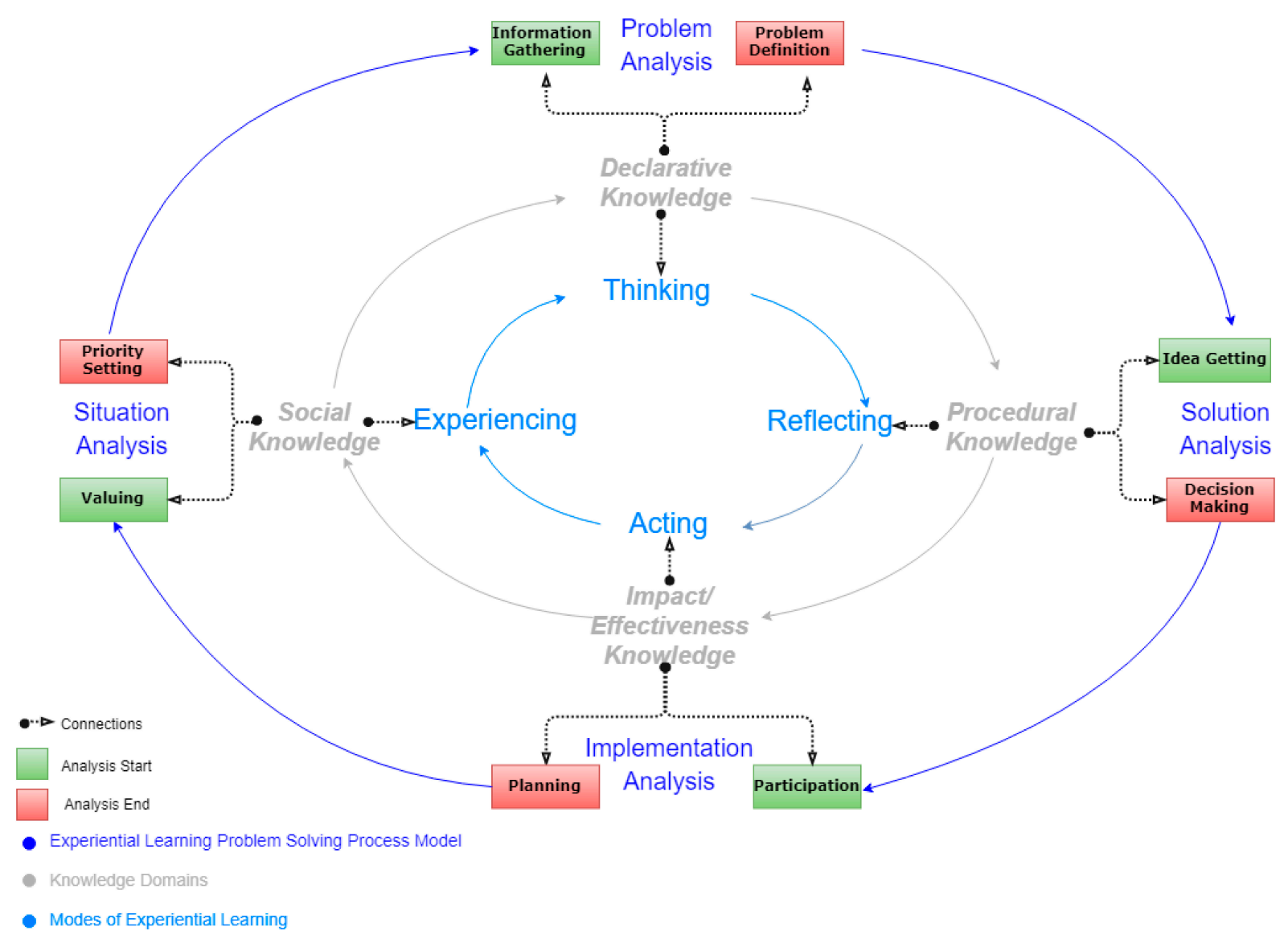

Figure 2. Experiential learning and knowledge domain interaction. Author developed based on work of Frisk \& Larson, 2011 and Kolb \& Kolb, 2009 [6,9]. 
At the start of the SEDV collaboration with TSO, declarative knowledge (top of Figure 2) was applied by expressing the dilemma. Furthermore, students were able to identify their specific role in the project based on the technical expertise or declarative knowledge that they gained in their traditional SEDV courses and undergraduate degrees. This corresponds with the Problem Analysis phase (at the top of Figure 2) in the experiential problem-solving process model [9]. At this stage, information is gathered, and the problem defined. Participants reviewed presentation material, conducted reviews of external literature, connected with civil society organizations that had worked in the region, and had sustained conversations with each other. Each student worked on his/her selected topic for the capstone research project.

Solution Analysis, the next problem-solving process phase, corresponds with the reflecting mode of learning. Here procedural knowledge was required. Challenges such as the scarcity of shea nut supply, inadequate water supply, very low literacy rates, poverty, technological limitations and donor requirements were considered, and solutions proposed. To do this the "how-to" procedural knowledge was needed to understand, for example, how shea nuts were locally processed to form shea butter. According to Kolb [9], this phase of the problem-solving process starts with getting and generating solutions and ends with making decisions on what should be done next.

As the term suggests, Implementation Analysis is the acting mode of the experiential learning cycle. It requires the use of Impact or Effectiveness type of knowledge. Here the "locus of control" [6] of participants determines how much influence or impact they believe they can provide to solving the problem. The higher the locus of control the more engaged the participants will become. The students in this case study maintained a high locus of control because at the project start each student determined which aspect of the project inspired him/her. With minimal supervision and guidance, they had autonomy over deriving methods to tackle emerging issues. The start and end nodes of this phase are participation and planning, which are influenced by effectiveness knowledge.

The begin and end nodes for the Situation Analysis phase are value and priority. Social knowledge was required in understanding the customs and traditions of the peoples in Pâ Village, but the moral norms of each participant influenced the choices made. The importance each participant placed on equity, environmental impacts or social justice determined the direction and bias of the individual student's research.

Experiential learning in management education, or in this case study regarding sustainability leadership, addresses the problem of secondhand and biased data in the learning experience. This is done when "the filtering process is reduced because teacher and student alike are observers of immediate experiences that they both interpret according to their own learning style. In this approach to learning, the teachers' role is 
that of facilitators of a learning process that is basically self-directed" ([9], p. 57).

\section{Building Leadership Competencies}

The University of Calgary's six foundational competencies are complementary to Wiek et al. [28] which outlined key sustainability competencies required to evaluate "learning and teaching effectiveness". According to Wiek "key competencies are a critical reference point for developing the ambitious knowledge and skill profile of students expected to be future 'problem solvers', 'change agents', and 'transition managers"' ([28], p. 204). The six foundational competencies evaluated include the following areas:

1. Anticipatory thinking and long-term foresightedness. The "ability to collectively analyze, evaluate, and craft rich 'pictures' of the future related to sustainability issues and sustainability problem-solving frameworks".

2. Empathy and understanding of different worldviews and relationships. Similar to Wiek's normative competency, which is "the ability to collectively map, specify, apply, reconcile, and negotiate sustainability values, principles, goals, and targets.... these skills are tailored to address key issues of sustainability including socio-ecological systems integrity, intra- and intergenerational equity".

3. Capacities for stakeholder engagement and group collaboration. It is an ability to provoke collaborative sustainability problem solving.

4. Action-oriented leadership skills and change agency skills. Like strategic competency this "competence is about being able to 'get things done'. This involves familiarity with real-world situations and relationships, political understanding, challenging positions at the right time, being able to solve logistical problems, using language that nonacademics are comfortable with, working with deadlines that governments insist on, and so forth".

5. Critical thinking and decision-making capacity within complexity.

6. Systems thinking and an understanding of connectedness. A skill required in addressing the main sustainability issues ([13,28], p. 33).

\section{MATERIALS AND METHODS}

For the implementation of the above-named framework, the University of Calgary and communities in Calgary and Burkina Faso were utilized for data collection. The overall research approach is case-based research in which the researchers investigate three prongs: (1) assessment of the accomplishments of the SDGs; (2) evaluation of the fulfillment of the sustainability competencies and leadership qualities; and (3) connection between the knowledge domains and the experiential learning process. The data were collected post-project implementation, and therefore the 
research was conducted by reflection and interviewing co-researchers following the steps outlined below.

\section{Assessment of the Accomplishment of the SDGs}

STEP 1: Identify how the successful implementation of the project met the SDG targets.

STEP 2: Collect data accumulated during the project planning, execution, and evaluation phases to determine the successes and challenges related to the project and its SDG targets.

\section{Evaluation of the Fulfillment of the Sustainability Competencies/Leadership Qualities}

STEP 3: Develop a framework using the past literature to identify documented sustainability education methods and competencies to illustrate theoretically how different knowledge domains and learning approaches influence students' contribution to project success.

STEP 4: Chronicle the students' interactions with the project to determine which decisions and actions steered their focus and hence the direction of the project.

\section{Connection between the Knowledge Domains and Experiential Learning}

STEP 5: Introduce the framework to the project participants and test by means of a reflective survey prior to the focus group discussion. Then, delve deeper into the survey questions through the focus group discussion. STEP 6: Refine and adapt the framework to the case study.

Steps 1 and 2 were achieved by determining if there was a consensus that the students' actions addressed four of the SDGs. Data were collected from the following sources: the TSO manager of the project; the professor from the University of Ouagadougou (Department of Physics, Laboratory of Physics and Chemistry of the Environment (LPCE); l'Association Monde Meilleur (AMM) who manages the project locally in Burkina Faso; and members of the Sougrinooma Women's Cooperative (Pâ village). Primary means of data gathering were observation, on-going monitoring of the project, and discussions with those who implemented and/or are benefiting from the project. Archival data from the University of Calgary and correspondence with students confirmed the reliability of the primary means of data gathering.

Steps 3 and 4 began by investigating the different knowledge domains and learning approaches that coalesce to build the University of Calgary's foundational competencies sufficiently for the student researchers to apply them through the capstone research project and produce tangible results. The framework developed in Figure 2 was drafted and analysed as a result of the data gathered in this step. To further investigate the validity of the framework, chronological communications and activities by the 
students, TSO, partner organizations and the project supervisors were analysed to determine the students' contributions at different phases of the project and the expertise demonstrated by the students at the end of the phase. The students' impacts on the project were evidenced by analyzing the steps taken to move forward in the project activities, which were often based on the students' recommendations.

Steps 5 and 6 are the primary focus of the results section of this paper. The feedback and comments from the student researchers illustrated in this section are also used as confirmation of this paper's framework. Due to the complexities involved in multi-lingual international research, the evaluation of the extent to which knowledge domains and an experiential learning approach team up for effective learning is based only on the responses of four Calgary-based students who undertook various aspects of the project as part of their SEDV capstone course. This study was approved by the Conjoint Faculties Research Ethics Board at University of Calgary (Ethics ID: REB16-1418) on August 26, 2016 as part of on-going research in the area of experiential learning. For this prong of the research, data were gathered through a series of questions in survey format that were sent to the four students (one of which is a co-author of this research). Questions were developed from experiential learning theory [9] and the knowledge domains based on the work of Frisk \& Larson [6]. Questions pertaining to sustainability leadership qualities were derived from the work of Wiek, et al. and Savage, Tapics, Evarts, Wilson, Tirone [28,29]. Students were asked to complete the survey electronically prior to a focus group discussion. The knowledge domain and experiential learning connection was established by having the respondents identify the knowledge used at distinct stages in their experiential learning progression. The questions and discussions were grouped to address three subjects:

1. achievement of sustainability leadership competencies;

2. application of the principles of experiential learning;

3. connection of the knowledge domains and experiential learning.

\section{RESULTS}

Just as the methods are three-pronged, the results will be discussed in the same format: (1) accomplishment of the SDGs; (2) development of competencies and leadership qualities; and (3) connection between the knowledge domains and experiential learning.

\section{Sustainable Development Goals}

Accomplishments to date in regard to the SDGs are provided in Tables 1 to 6 . Each goal and sub-goal that pertained to this project is listed along with the target and indicator for the goal. Then the Burkina Faso project contribution in meeting those requirements [18] is explained. 
SDG 4: Quality education

The project contribution to this goal is specific to the student researchers and as such only Target 4.7 is assessed. Details are provided in Table 1.

Table 1. SDG 4 and the SEDV program contribution.

\begin{tabular}{|c|c|c|c|}
\hline \multicolumn{4}{|c|}{ Goal 4: Quality Education } \\
\hline Target & Indicator & $\begin{array}{l}\text { SEDV Research Course } \\
\text { Contribution }\end{array}$ & Lesson Learned \\
\hline $\begin{array}{l}4.7 \text { By } 2030 \text {, ensure that all learners } \\
\text { acquire the knowledge and skills } \\
\text { needed to promote sustainable } \\
\text { development, including, among } \\
\text { others, through education for } \\
\text { sustainable development and } \\
\text { sustainable lifestyles, human } \\
\text { rights, gender equality, promotion } \\
\text { of a culture of peace and non- } \\
\text { violence, global citizenship and } \\
\text { appreciation of cultural diversity } \\
\text { and of culture's contribution to } \\
\text { sustainable development. }\end{array}$ & $\begin{array}{l}\text { 4.7.1 Extent to which } \\
\text { (i) global citizenship } \\
\text { education and (ii) } \\
\text { education for sustainable } \\
\text { development, including } \\
\text { gender equality and } \\
\text { human rights, are } \\
\text { mainstreamed at all levels } \\
\text { in: (a) national education } \\
\text { policies, (b) curricula, (c) } \\
\text { teacher education and (d) } \\
\text { student assessment. }\end{array}$ & $\begin{array}{l}\text { The research course } \\
\text { prepared the students to } \\
\text { apply and develop } \\
\text { sustainability competencies. } \\
\text { The women in the } \\
\text { community of Pâ also built } \\
\text { their confidence. It also led } \\
\text { to the design of the Needs } \\
\text { Assessment completed } \\
\text { through group and } \\
\text { individual surveys. }\end{array}$ & $\begin{array}{l}\text { While development } \\
\text { projects can instigate } \\
\text { sustainable growth, the } \\
\text { student involvement should } \\
\text { not be limited to the } \\
\text { research period. Three of } \\
\text { the four student } \\
\text { researchers continued to } \\
\text { assist with the project post } \\
\text { SEDV graduation. The } \\
\text { continuity helped during } \\
\text { project execution and } \\
\text { impact assessment. }\end{array}$ \\
\hline
\end{tabular}

Related to quality education for everyone, after a visit to the project site, a project supervisor (teacher) and member of the project team made the comment:

"The thing I felt most when we were at the village and talking to the women was... they were in the courtyard of the mosque and the row of men were sitting with their backs to the mosque...that there was that gender distinction from the beginning. I found it hard to engage the women.... there is possibly a need to reinforce their voice so that the decisions are not just made by the men."

Gender equality by meeting the needs of the women, and constructing a financially viable, technically sound, environmentally friendly facility became the goal of each student. Students also demonstrated that systems thinking (a sustainability competency) is required to fulfil Goal 4:

"I appreciated a deeper understanding... being aware of some of the other environmental aspects you have to consider. Like you think solar power is perfectly green, that it is great; but you [also] have to think 'what about the batteries that are needed? How are those disposed in that part of the world?' ... like the life cycle analysis.... You think about them [other environmental aspects] more if you want to consider the full cycle of sustainability." (Student 2) 
SDG 7: Affordable and clean energy; ensure access to affordable, reliable, sustainable and modern energy for all

The Power Hub satisfied Goal 7 by providing access to clean affordable energy and thus it also ensures intergenerational social mobility. Table 2 demonstrates how the project satisfied these requirements.

Table 2. SDG 7 and Power Hub project contribution.

\begin{tabular}{|c|c|c|c|}
\hline \multicolumn{4}{|c|}{ Goal 7: Affordable and Clean Energy } \\
\hline Target & Indicator & Project Contribution & Lessons Learned \\
\hline $\begin{array}{l}7.1 \text { By } 2030 \text {, ensure universal access } \\
\text { to affordable, reliable and modern } \\
\text { energy services. }\end{array}$ & $\begin{array}{l}\text { 7.1.1 Proportion of } \\
\text { population with } \\
\text { access to electricity }\end{array}$ & $\begin{array}{l}\text { Provided access to } 3 \text { solar } \\
\text { milling machines for } 100 \\
\text { members of Sougrinooma } \\
\text { Women's Cooperative with } \\
\text { indirect benefits applicable } \\
\text { to approximately } 10,000 \\
\text { members of the broader } \\
\text { community. }\end{array}$ & $\begin{array}{l}\text { The project impact assessment } \\
\text { revealed a need for faster and } \\
\text { more powerful milling } \\
\text { equipment. Therefore, a grid } \\
\text { powered alternative was } \\
\text { considered and later } \\
\text { implemented. }\end{array}$ \\
\hline $\begin{array}{l}7.2 \text { By } 2030 \text {, increase substantially } \\
\text { the share of renewable energy in the } \\
\text { global energy mix. }\end{array}$ & $\begin{array}{l}\text { 7.2.1 Renewable } \\
\text { energy share in the } \\
\text { total final energy } \\
\text { consumption }\end{array}$ & $\begin{array}{l}\text { Sougrinooma Women's } \\
\text { Cooperative switched from a } \\
100 \% \text { manual milling of shea } \\
\text { and flour to } 50 \% \text { automated } \\
\text { milling with renewable } \\
\text { energy. }\end{array}$ & $\begin{array}{l}\text { The addition of grid powered } \\
\text { equipment will reduce the } \\
\text { contribution of renewable } \\
\text { energy powered equipment. }\end{array}$ \\
\hline $\begin{array}{l}\text { 7.B By 2030, expand infrastructure } \\
\text { and upgrade technology for } \\
\text { supplying modern and sustainable } \\
\text { energy services for all in developing } \\
\text { countries, in particular least } \\
\text { developed countries, small island } \\
\text { developing States, and land-locked } \\
\text { developing countries, in accordance } \\
\text { with their respective programmes of } \\
\text { support. }\end{array}$ & Not applicable & $\begin{array}{l}\text { Burkina Faso has Wi-Fi } \\
\text { services. Pending } \\
\text { optimization, the Wi-Fi will } \\
\text { be available to the 10,000 } \\
\text { residents of Pâ. }\end{array}$ & $\begin{array}{l}\text { The technology is currently } \\
\text { producing a weak signal and } \\
\text { the satellite communications } \\
\text { provider is working with TSO } \\
\text { to resolve. }\end{array}$ \\
\hline
\end{tabular}

SDG 8: Decent work and economic growth; promote sustained, inclusive and sustainable economic growth, full and productive employment and decent work for all

Inclusivity of the project beneficiaries was vital to the promotion of sustainable economic growth and decent work for all. The project's Needs Assessment identified a gender inequality in literacy and consequent economic opportunities as illustrated in Figure 3. 


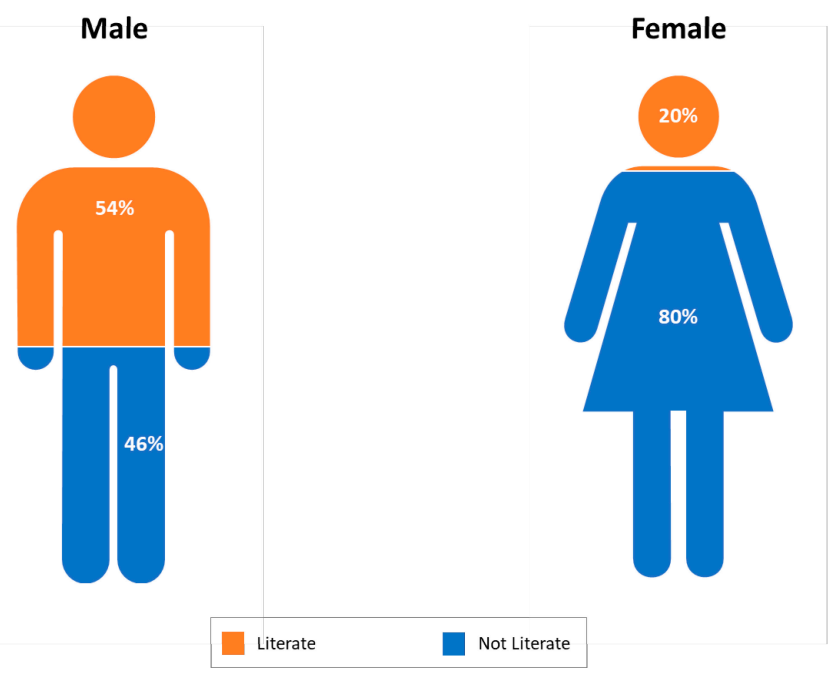

Figure 3. Literacy rate from survey conducted.

To address this concern two training sessions were organized: an entrepreneurship training by the University of Ouagadougou (see Figure 4), and a soap-making and shea business management training conducted by the Yona Women's Cooperative, a regional cooperative sponsored by Foundation Semafo of Montreal, Quebec (see Figure 5). Revenue for Sougrinooma previously came only from commodity-based sales. By including a soap-making machine at the facility after the training, the project created job opportunities that simultaneously met the needs of the community. Table 3 summarizes the implementation of SDG 8 for the project.

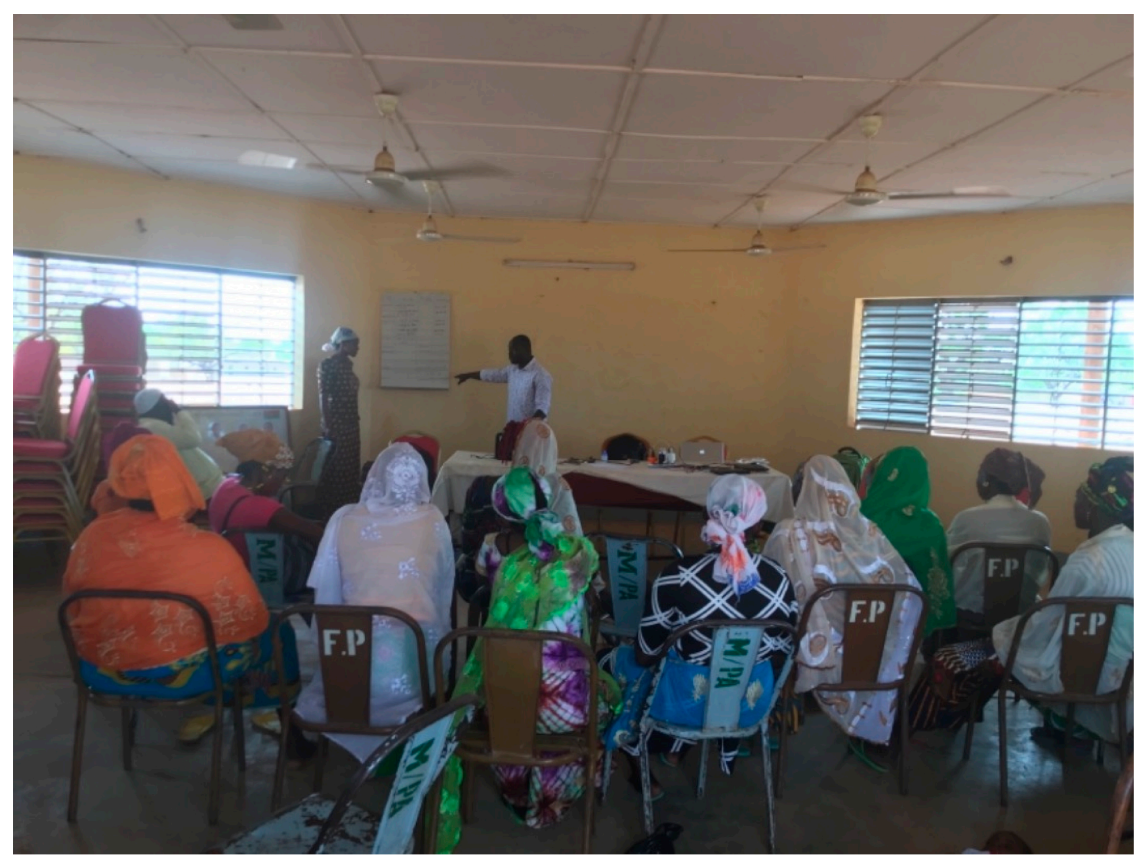

Figure 4. Entrepreneurship training conducted by the University of Ouagadougou for the Sougrinooma Women's Cooperative. 


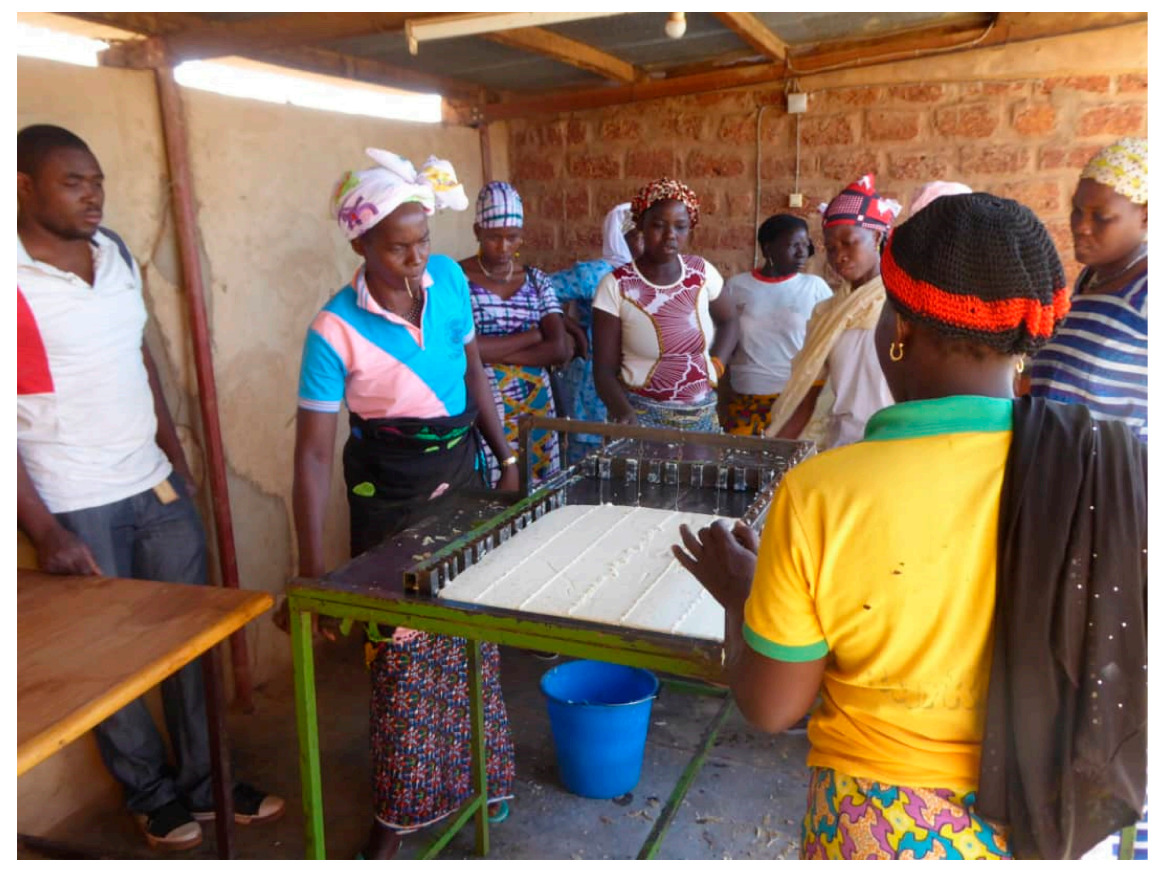

Figure 5. Yona women's soap-making training with the Sougrinooma Women's Cooperative.

Table 3. SDG 8 and Power Hub project contribution.

\begin{tabular}{|c|c|c|c|}
\hline \multicolumn{4}{|c|}{ Goal 8: Decent Work and Economic Growth } \\
\hline Target & Indicator & Project Contribution & Lessons Learned \\
\hline $\begin{array}{l}8.2 \text { Achieve higher levels of } \\
\text { economic productivity through } \\
\text { diversification, technological } \\
\text { upgrading and innovation, } \\
\text { including through a focus on } \\
\text { high-value-added and labour- } \\
\text { intensive sectors. }\end{array}$ & Not applicable & $\begin{array}{l}\text { Sougrinooma diversified its income } \\
\text { stream from shea nut processing to } \\
\text { café and milling services. As of } \\
\text { March 31, 2019, the revenue stream } \\
\text { was } 44 \% \text { café; } 26 \% \text { milling; } 14 \% \\
\text { office services; } 8 \% \text { Wi-Fi; } 6 \% \text { solar } \\
\text { lantern sales; } 2 \% \text { cellphone } \\
\text { charging. }\end{array}$ & $\begin{array}{l}\text { The financial model served as } \\
\text { a guide. Local conditions and } \\
\text { remote planning made it } \\
\text { difficult to totally understand } \\
\text { the intricacies involved in } \\
\text { running the Wi-Fi service } \\
\text { (expected to be the top } \\
\text { income generator). }\end{array}$ \\
\hline $\begin{array}{l}8.5 \text { By } 2030 \text {, achieve full and } \\
\text { productive employment and } \\
\text { decent work for all women and } \\
\text { men, including for young } \\
\text { people and persons with } \\
\text { disabilities, and equal pay for } \\
\text { work of equal value. }\end{array}$ & $\begin{array}{l}\text { 8.5.1 Average hourly } \\
\text { earnings of female } \\
\text { and male employees, } \\
\text { by occupation, age } \\
\text { and persons with } \\
\text { disabilities }\end{array}$ & $\begin{array}{l}\text { Project beneficiary's income has } \\
\text { increased due to the diversification } \\
\text { of their revenue streams. }\end{array}$ & $\begin{array}{l}\text { The impact survey revealed } \\
\text { that some women did not } \\
\text { increase their income and } \\
\text { others could not confirm their } \\
\text { income because they are not } \\
\text { in charge of their finances. }\end{array}$ \\
\hline $\begin{array}{l}8.6 \text { By } 2020 \text {, substantially } \\
\text { reduce the proportion of youth } \\
\text { not in employment, education } \\
\text { or training. }\end{array}$ & $\begin{array}{l}\text { 8.6.1 Proportion of } \\
\text { youth (aged 15-24 } \\
\text { years) not in } \\
\text { education, } \\
\text { employment or } \\
\text { training }\end{array}$ & $\begin{array}{l}\text { The Power Hub employs } 12 \text { part- or } \\
\text { full-time residents including } 2 \\
\text { young adults as interns. Staff } \\
\text { includes } 6 \text { female youth from the } \\
\text { Sougrinooma Women's } \\
\text { Cooperative. }\end{array}$ & $\begin{array}{l}41.46 \% \text { of those surveyed in } \\
\text { the impact assessment and } \\
\text { employed by the Power Hub } \\
\text { are } 29 \text { years old and younger. }\end{array}$ \\
\hline
\end{tabular}

Students noted during the focus group discussion that without the community inclusion at the project planning phase by way of two town 
halls conducted in Pâ (see Figure 6), the chances of executing the project on time and budget would have been improbable.

"I still remember how the guy from company $X$ wanted to do one thing with the project. Then from the interviews conducted with the people in Burkina, they [the village residents] had a whole separate list of what they felt the project might look like. I thought that it was certainly interesting because you can have this idea on how you think the project is going to turn out and that's not actually what they want.”

This observation is an example of the type of social knowledge experienced in Situation Analysis (Experiential Learning Problem-Solving Process Model).

(A)

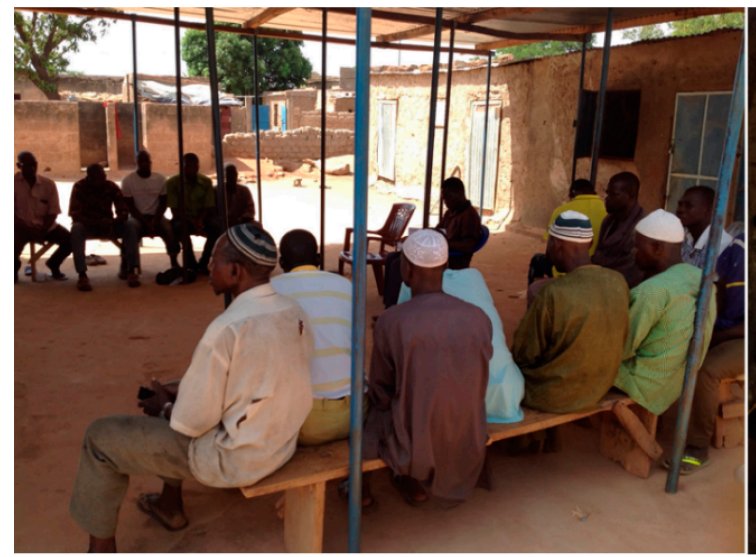

(B)

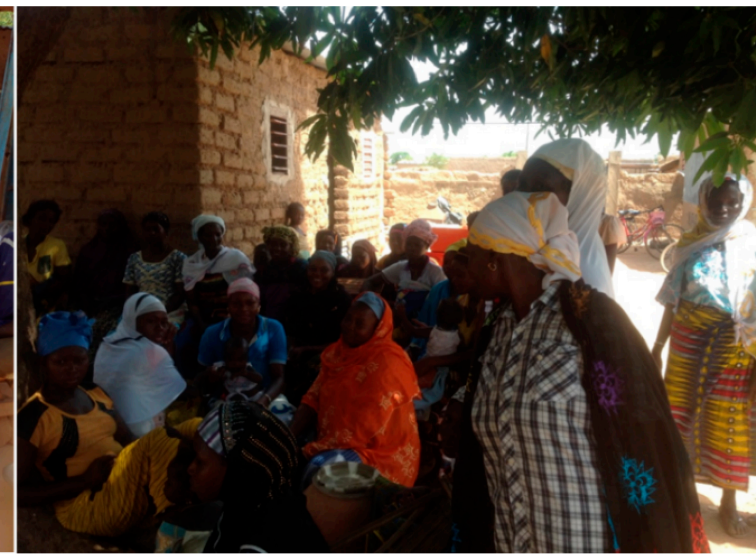

Figure 6. Pâ community planning phase town hall meetings. (A) Town hall for men (Left). (B) Women's town hall (Right).

SDG 9: Industry, innovation and infrastructure; build resilient infrastructure, promote inclusive and sustainable industrialization and foster innovation

Innovation and partnerships (especially local) supported project delivery and the fabrication of the Power Hub. The sea container was locally sourced, thereby reducing costs but also enabling the contractor to implement an alternative for transferring larger equipment, which had not been considered by the team in Calgary. Table 4 provides the summary (also see Figure 7). 
Table 4. SDG 9 and Power Hub project contribution.

\begin{tabular}{|c|c|c|c|}
\hline \multicolumn{4}{|c|}{ Goal 9: Industry, Innovation and Infrastructure } \\
\hline Target & Indicator & Project Contribution & Lessons Learned \\
\hline $\begin{array}{l}9.3 \text { Increase the access of small-scale } \\
\text { industrial and other enterprises, in } \\
\text { particular in developing countries, to } \\
\text { financial services, including affordable } \\
\text { credit, and their integration into value } \\
\text { chains and markets. }\end{array}$ & $\begin{array}{l}\text { 9.3.1 Proportion of } \\
\text { small-scale } \\
\text { industries in total } \\
\text { industry value } \\
\text { added }\end{array}$ & $\begin{array}{l}\text { Soap making machines were } \\
\text { purchased to help transition } \\
\text { Sougrinooma from } \\
\text { commodity-based sales to } \\
\text { value added finished goods } \\
\text { sales. }\end{array}$ & $\begin{array}{l}\text { Capacity building was } \\
\text { integral in making the } \\
\text { transition from } \\
\text { commodity-based sales to } \\
\text { value-added goods. }\end{array}$ \\
\hline $\begin{array}{l}\text { 9.C Significantly increase access to } \\
\text { information and communications } \\
\text { technology and strive to provide } \\
\text { universal and affordable access to the } \\
\text { Internet in least developed countries by } \\
2020 \text {. }\end{array}$ & $\begin{array}{l}\text { 9.C.1 Proportion of } \\
\text { population } \\
\text { covered by a } \\
\text { mobile network, } \\
\text { by technology }\end{array}$ & $\begin{array}{l}\text { Wi-Fi access is a revenue } \\
\text { stream from the project. Wi-Fi } \\
\text { service is being optimized to } \\
\text { provide uninterrupted service } \\
\text { to the entire community. }\end{array}$ & $\begin{array}{l}\text { Access to the internet } \\
\text { requires more than } \\
\text { electricity. Infrastructure } \\
\text { as well as a reliable service } \\
\text { provider are crucial. }\end{array}$ \\
\hline
\end{tabular}

(A) Window and door cut out.

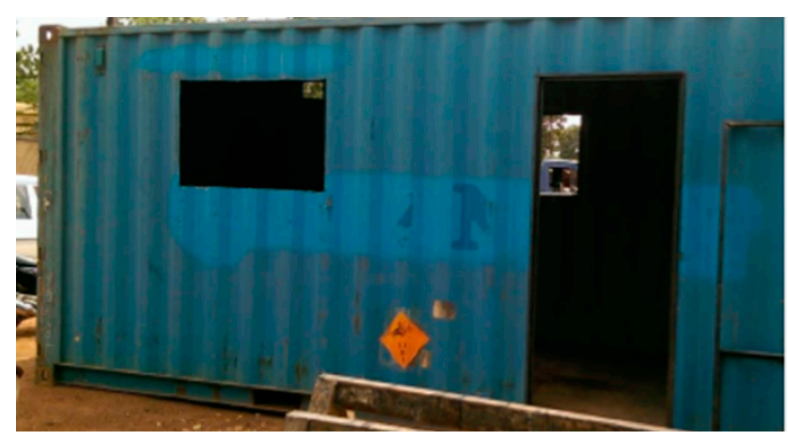

(C) Window and door fitted.

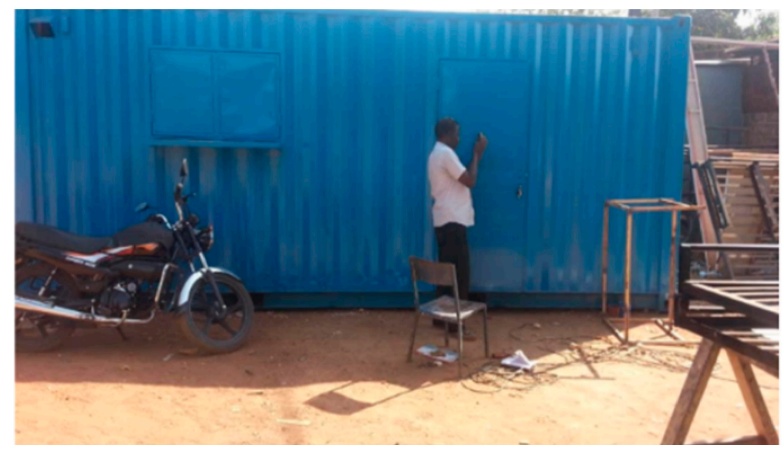

(B) Fitting the window frame.

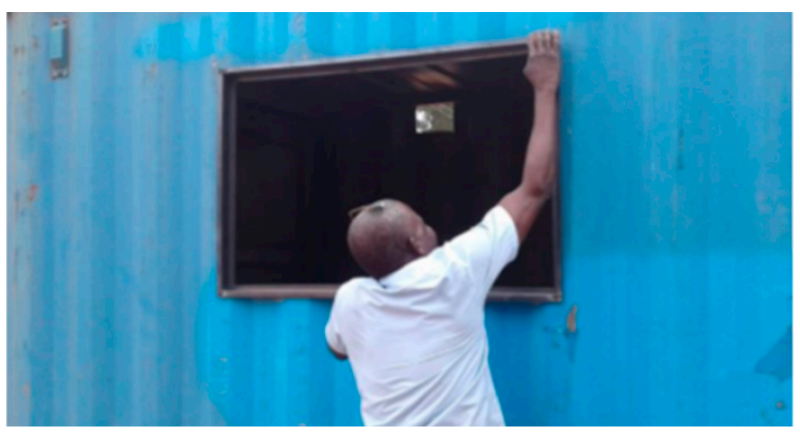

(D) Lock on the door for security.

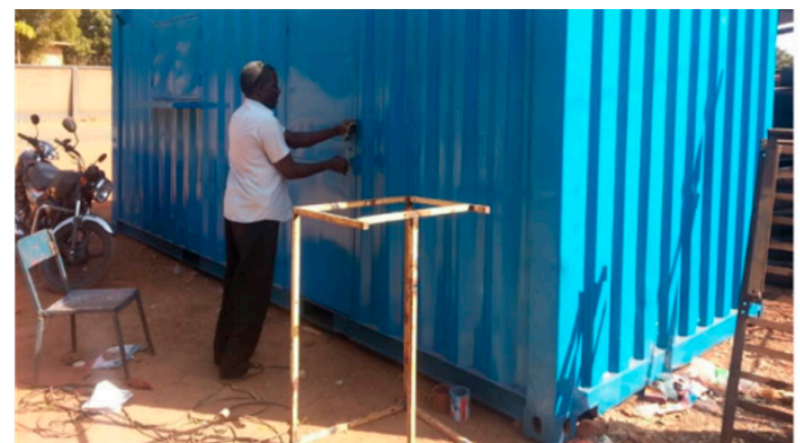

Figure 7. Fabrication of container in Burkina Faso.

SDG 17: Partnerships for the goals; strengthen the means of implementation and revitalize the global partnership for sustainable development

SDG 17 is a means of achieving the targets of the other goals. Multiple partners were engaged in the planning and execution phase of the project to ensure a resilient facility (See Table 5).

Table 6 provides details on the project's contribution to SDG 17. 
Table 5. Partner organizations and their contributions.

\begin{tabular}{ll}
\hline Partner Organization & Contribution \\
\hline Solar Milling (Spain) & Provided solar milling equipment and knowledge transfer. \\
Schneider Electric Foundation (Canada) & Conducted solar system sizing, load profiling, and electrical design. \\
& Supplied electrical equipment. \\
University of Ouagadougou (Burkina Faso) & Conducted needs assessment and entrepreneurial training. \\
Total (Burkina Faso) & Provided solar lanterns for leasing to the community. \\
Telecom Afrique (France) & Installed and supplied Wi-Fi. \\
University of Calgary & Conducted research, rendering of concept, undertook site visits. \\
La Source Nouvelle (Burkina Faso) & Serviced and supports solar equipment. \\
AMM (Burkina Faso) & Conducted project management. \\
Sougrinooma Women's Cooperative & Contributors in execution phase and project beneficiaries. \\
Foundation Semafo (Montreal and Burkina Faso) & Shared their lessons learned in project planning phase and delivered \\
& capacity building to Sougrinooma via Yona Cooperative. \\
Lush Cosmetics Inc. & Contributed financial resources. \\
The Rotary Club of Calgary Downtown & Contributed financial resources. \\
\hline
\end{tabular}

Table 6. SDG 17 and Power Hub project contribution.

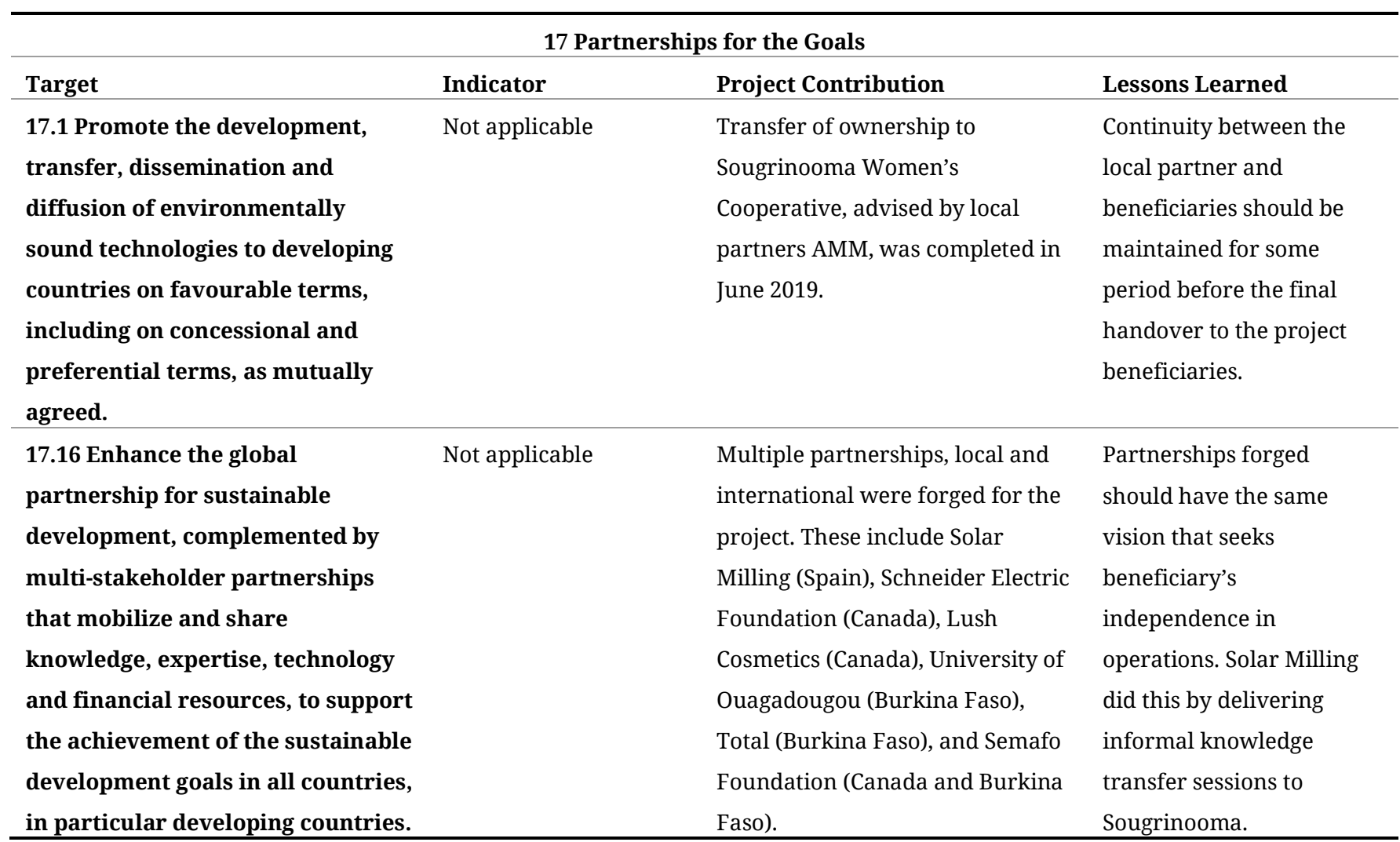


Table 6. Cont.

\begin{tabular}{|c|c|c|c|}
\hline \multicolumn{4}{|c|}{17 Partnerships for the Goals } \\
\hline Target & Indicator & Project Contribution & Lessons Learned \\
\hline $\begin{array}{l}17.7 \text { Enhance North-South, South- } \\
\text { South and triangular regional and } \\
\text { international cooperation on and } \\
\text { access to science, technology and } \\
\text { innovation and enhance } \\
\text { knowledge sharing on mutually } \\
\text { agreed terms, including through } \\
\text { improved coordination among } \\
\text { existing mechanisms, in particular } \\
\text { at the United Nations level, and } \\
\text { through a global technology } \\
\text { facilitation mechanism. }\end{array}$ & $\begin{array}{l}\text { 17.7.1 Total amount of } \\
\text { approved funding for } \\
\text { developing countries to } \\
\text { promote the } \\
\text { development, transfer, } \\
\text { dissemination and } \\
\text { diffusion of } \\
\text { environmentally sound } \\
\text { technologies }\end{array}$ & $\begin{array}{l}\text { The Power Hub contributed to the } \\
\text { development and transfer of } \\
\text { "environmentally sound technologies.” A } \\
\text { manufacturer in Mali provided panels and } \\
\text { batteries; technicians in Burkina Faso } \\
\text { installed them. Telecom Afrique, a French } \\
\text { company, supplied the Wi-Fi equipment. A } \\
\text { local Burkina partner serviced and } \\
\text { supported the Wi-Fi. A Spanish company } \\
\text { provided solar milling machines and } \\
\text { knowledge transfer. University of } \\
\text { Ouagadougou conducted entrepreneurial } \\
\text { training. }\end{array}$ & \\
\hline $\begin{array}{l}17.9 \text { Enhance international } \\
\text { support for implementing } \\
\text { effective and targeted capacity- } \\
\text { building in developing countries to } \\
\text { support national plans to } \\
\text { implement all the sustainable } \\
\text { development goals, including } \\
\text { through North-South, South-South } \\
\text { and triangular cooperation. }\end{array}$ & $\begin{array}{l}\text { 17.9.1 Dollar value of } \\
\text { financial and technical } \\
\text { assistance (including } \\
\text { through North-South, } \\
\text { South-South and } \\
\text { triangular cooperation) } \\
\text { committed to } \\
\text { developing countries }\end{array}$ & $\begin{array}{l}\text { The estimated cost of the project was } \\
\$ 100,000 \text {. Of the total budget, } 15 \% \text { was } \\
\text { allocated to capacity building and training. }\end{array}$ & $\begin{array}{l}\text { Security concerns } \\
\text { made it difficult } \\
\text { to have } \\
\text { volunteers from } \\
\text { Schneider } \\
\text { Electric conduct a } \\
\text { pre-arranged } \\
\text { training } \\
\text { program. }\end{array}$ \\
\hline
\end{tabular}

The women of the cooperative invested in-kind to the project by clearing donated land for the start of construction. See Figure 8.

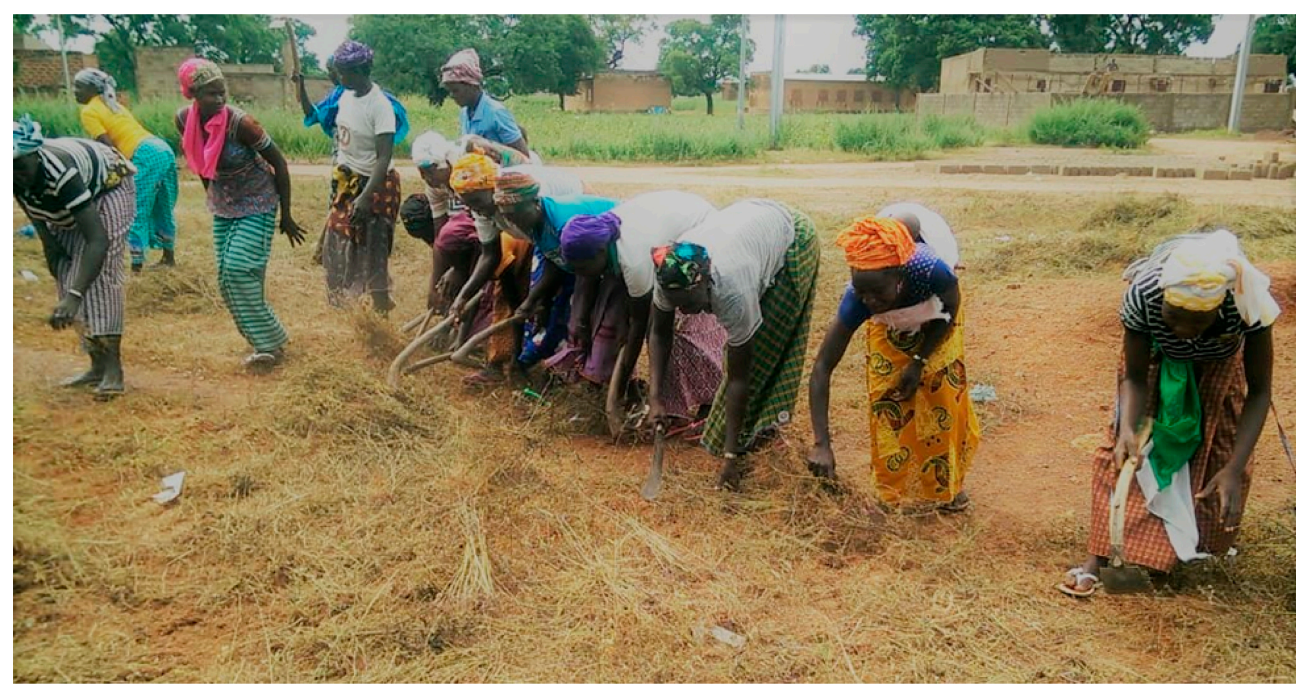

Figure 8. Sougrinooma Women's Cooperative's contributing to the project construction. 


\section{Development of the Sustainability Leadership Competencies}

The six foundational competencies that University of Calgary students should develop through education in sustainability include anticipatory thinking, empathy, collaborative, action-oriented leadership, critical thinking, and systems thinking competencies [13].

After the project was presented to the SEDV capstone class, interested students were requested to apply for the research opportunity, indicating how they intended to help TSO achieve its objective of converting solarpowered renewable energy into sustainable village wealth. On approval, each student had to submit a proposal with further detail on the research question, its relevance, methodology, etc. To accomplish this the students independently assessed what they could contribute and the anticipated challenges. The development and use of anticipatory thinking were required in analyzing and proposing sustainable methods to solve the anticipated challenges and achieve the project's goals. The research questions from the proposals required anticipatory analysis:

"What is the potential communal energy demand associated with the development of a small renewable power-station (hub) intended to promote the sustainable development of an off-grid and remote village in Burkina Faso, West Africa?” (Student 1)

"What business model will allow for an economically feasible off-grid village-based solar project in the country of Burkina Faso?" (Student 2)

"Is trade seen as critical to the local community? Will sustainable energy development and entrepreneurial trade in Burkina Faso accelerate long-lasting socio-economic growth?” (Student 3)

"What type/size of renewable energy system could be implemented to most effectively power a village in Burkina Faso?” (Student 4)

Based on feedback from TSO, the students jointly developed a work plan to address specific goals which included answering questions, similar to the following:

- How can businesses use the power for economic development to then sell goods and services to consumers? Are there profitable business models that are feasible?

- What are the cultural implications of installing a power facility? How will Burkina Faso residents take ownership?

- What will the facility look like and how much power will it produce?

- How will consumers use the power produced for a better quality of life and how much will they need to produce?

The project requirement of having the student researchers specify and collectively map sustainability targets required the development of critical 
and systems thinking competencies. The initial work plan developed by the students is presented in Figures 9 and 10.

\begin{tabular}{|c|c|c|c|c|c|c|c|c|}
\hline \multicolumn{2}{|r|}{ Focus } & \multicolumn{4}{|c|}{ Capstone } & \multicolumn{3}{|c|}{ Volunteer } \\
\hline Assessment & Task & 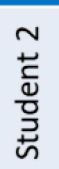 & $\begin{array}{l}+ \\
\stackrel{0}{0} \\
\text { d } \\
\frac{\overrightarrow{0}}{2} \\
\dot{H}\end{array}$ & 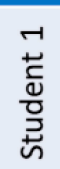 & 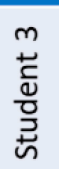 & 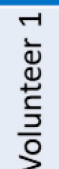 & 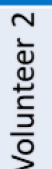 & 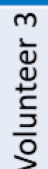 \\
\hline \multirow{4}{*}{ Environment } & Impact on Culture & • & & & & & & \\
\hline & Energy Use Change/Impact & & & $\bullet$ & & & & \\
\hline & Power Hub Footprint & & $\bullet$ & & & & & \\
\hline & Impact Financial Activity & & & & $\bullet$ & & & \\
\hline \multirow{5}{*}{ Society } & Demographics & $\bullet$ & & & & & & \\
\hline & Culture/Beliefs & $\bullet$ & & & & & & \\
\hline & Needs Assessment & - & & & & & & \\
\hline & Community Impact & $\bullet$ & & & & & & \\
\hline & Community Capacity Building & - & & & & • & & \\
\hline \multirow{4}{*}{ Economics/Business } & Power Hub Cost Analysis & & $\bullet$ & & & & & \\
\hline & Consumer Finance Model & & & & $\bullet$ & & & \\
\hline & Business Finance Model & & & & $\bullet$ & & & \\
\hline & Implementation Funding & & & & $\bullet$ & & $\bullet$ & \\
\hline \multirow{4}{*}{ Energy Demand } & Consumer Energy Demand/Use & & & $\bullet$ & & & & \\
\hline & Business Energy Demand/Use & & & $\bullet$ & & & & \\
\hline & Appliance \& Machine Technology & & & $\bullet$ & & & & \\
\hline & Industry/Business Development & & & $\bullet$ & & & & \\
\hline \multirow{4}{*}{ Power Hub Design } & Resource Data Collection & & • & $\bullet$ & & & & \\
\hline & Power Technology Selection & & $\bullet$ & & & & & \\
\hline & Power Hub Design & & $\bullet$ & & & & & \\
\hline & Supply Chain & & $\bullet$ & & & & & ○ \\
\hline
\end{tabular}

Figure 9. Initial project work plan developed by SEDV research student (original content by Student 1).

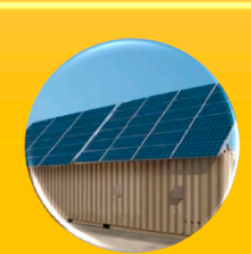

Technical Assessment

- Conceptual power hub design

- Solar/wind capacity assessment

- Implementation and logistics

- Current demand for energy

- Consumer and Business

- Potential future demand for energy

- Consumer and Business

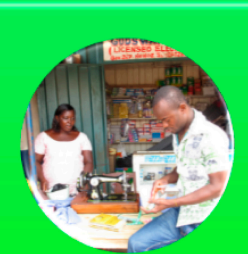

Economic Assessment

- Consumer and Business Economics

- Financial capacity

- Finance model

- Power hub cost analyses

- Future Industry

- Funding

- Stakeholders

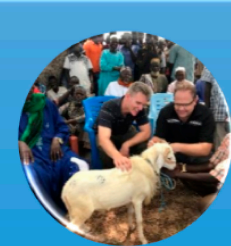

Social Assessment

- Community acceptance

- Individual and group dynamics

- Capacity building

- Needs and wants

- Impact to people

\section{Environment}

Figure 10. Boundaries of research topics, defined by student researchers (original content by Student 1). 
The rate of competency development by the student researchers varied, and therefore Student 1 took on a leadership role at the start of the project by demonstrating and/or developing action-oriented leadership by organizing weekly researcher meetings, proposing a schedule with key milestones, etc. Other students developed this competency by the end of the project by "getting things done" in a first-of-its-kind remotely run operation.

During the focus group discussion, participants confirmed that the diverse and multi-stakeholder environment was conducive to the development of interpersonal competencies:

"The most easily identifiable one [leadership competency] for me is navigating discussions with so many stakeholders... [It is] certainly not something I've done in my professional personal career. I worked for companies that just kind of steam-rolled their way through, so [adjusting was] definitely interesting." (Student 2)

"I'd say I developed teamwork skills and the ability to work on a multidisciplinary project dealing with the different skill sets and people with different backgrounds... communication is always a big one in any leadership or team environment and I certainly developed that through this project.... Probably communication and collaboration." (Student 4)

The requirements of the project enabled the Power Hub project participants to acquire multiple sustainability leadership competencies while achieving the SDGs.

\section{The Knowledge Domains and Experiential Learning Connection}

The experiential learning problem-solving process model and knowledge domains were used to varying extents by the individuals involved in the project, as well as by the project as a whole. For example, in terms of the experiential learning principle of "making spaces for acting and reflecting” [9], the students mentioned:

"I would say I probably spent just as much time thinking about what we talked about in the meeting and what every single individual stakeholder was looking to get out of the project. Probably about as much time as we spent in the meetings, I spent as much time out of the meetings thinking about that stuff." (Student 2)

"After the meetings I would review my notes and try to recall everyone's comments and how that would kind of frame not only my project but the whole Power Hub project." (Student 4)

All the respondents felt in control of their research, repeatedly practiced what interested them, experienced fascination and interest for their work, had meaningful conversations about the project, and experienced the "support of the learning community". This was confirmed 
by Student 4, who recalled her experience with the TSO project owner; "He always said: What do you think is best?"

During the focus group discussion, the existence of the experiential learning was confirmed not only in the capstone research course but through the SEDV program.

"For me I found our entire [SEDV] program was tailored towards real world applications. So, the transition between our program and this project, I actually didn't find to be that much of a stretch.... Our program was a lot of looking at real examples of things." (Student 2)

The analysis establishing the connection between the knowledge domains and experiential learning is done at varying stages of the individual student's participation. Table 7 highlights the knowledge demonstrated by the four students at the different experiential learning points.

Table 7. Experiential learning-knowledge domain connection as demonstrated by research students' activities.

\begin{tabular}{|c|c|c|}
\hline Student Engagement & $\begin{array}{l}\text { Experiential } \\
\text { Learning Problem- } \\
\text { Solving Nodes }\end{array}$ & Knowledge Domain \\
\hline \multicolumn{3}{|l|}{ Problem Analysis } \\
\hline $\begin{array}{l}\text { Student } 3 \text { conducted multiple semi-structured interviews with the Executive } \\
\text { Director of Semafo Foundation, a professor at the University of Ouagadougou, an } \\
\text { NGO partner, and a post-site visit interview of a project team member and } \\
\text { University of Calgary professor. }\end{array}$ & $\begin{array}{l}\text { Information } \\
\text { Gathering }\end{array}$ & $\begin{array}{l}\text { Declarative } \\
\text { Knowledge }\end{array}$ \\
\hline $\begin{array}{l}\text { A SWOT analysis and list of recommendation was drafted from the interviews. } \\
\text { Potential threats like the scarcity of shea nuts from October to May (dry season) } \\
\text { was highlighted and provision made to purchase inventory from the market at } \\
\text { retail price. }\end{array}$ & Problem Definition & $\begin{array}{l}\text { (Knowledge of how } \\
\text { systems work) }\end{array}$ \\
\hline \multicolumn{3}{|l|}{$\begin{array}{ll} & \text { Solution Analysis } \\
\end{array}$} \\
\hline $\begin{array}{l}\text { To arrive at a technical solution to the electricity challenge in Pâ, Student } 4 \\
\text { researched and generated a comparison chart of potential off-grid solar energy } \\
\text { solutions like BBOX, Off Grid Box, SolarTurtle, etc. }\end{array}$ & Idea Getting & $\begin{array}{l}\text { Procedural } \\
\text { Knowledge }\end{array}$ \\
\hline $\begin{array}{l}\text { Parameters such as the Solar Photovoltaic (PV) panel array, PV mount type, } \\
\text { container size, maintenance requirement, battery type, battery recycling, etc. } \\
\text { provided the information needed to make an informed decision on the adopted } \\
\text { technology. }\end{array}$ & Decision Making & $\begin{array}{l}\text { (Knowledge of how } \\
\text { to achieve a } \\
\text { particular goal) }\end{array}$ \\
\hline
\end{tabular}


Table 7. Cont.

\begin{tabular}{|c|c|c|}
\hline Student Engagement & $\begin{array}{c}\text { Experiential Learning } \\
\text { Problem-Solving } \\
\text { Nodes }\end{array}$ & Knowledge Domain \\
\hline \multicolumn{3}{|l|}{ Implementation Analysis } \\
\hline $\begin{array}{l}\text { To gain a better understanding on how the project recipients might "process } \\
\text { information to match their values, beliefs, or behaviors" [9], a Needs } \\
\text { Assessment was conducted by Student } 2 \text { in collaboration with the University } \\
\text { of Ouagadougou partners. The result indicated that Pâ residents would be } \\
\text { willing to adopt the new technology. }\end{array}$ & Participation & \multirow{2}{*}{$\begin{array}{l}\text { Impact/Effectiveness } \\
\text { Knowledge } \\
\text { (Knowledge on the } \\
\text { relative effectiveness } \\
\text { of behaviours, to reach } \\
\text { a certain outcome) }\end{array}$} \\
\hline $\begin{array}{l}\text { Based on the results from the Needs Assessment, a capacity building } \\
\text { requirement was identified and working closely with TSO, AMM, Semafo } \\
\text { Foundation, and the University of Ouagadougou, training sessions were } \\
\text { organized for the project recipients. }\end{array}$ & Planning & \\
\hline \multicolumn{3}{|l|}{ Situation Analysis } \\
\hline $\begin{array}{l}\text { The Power Hub remained an abstract concept till Student } 1 \text { illustrated what } \\
\text { he believed the site represented to him and TSO. }\end{array}$ & Valuing & \\
\hline $\begin{array}{l}\text { Purposes like project execution (construction), fund raising, project } \\
\text { promotion, and education of partners were considered in determining the } \\
\text { best representation. After proposing options like 3D modeling, traditional } \\
\text { models, and architectural drawings, Student } 1 \text { worked with a University of } \\
\text { Calgary Architectural student to develop the Power Hub rendering used } \\
\text { during the project planning and execution phase. The rendering effectively } \\
\text { addressed the concerns of the involved parties. }\end{array}$ & Priority Setting & $\begin{array}{l}\text { Social Knowledge } \\
\text { (Knowledge on the } \\
\text { motives and intentions } \\
\text { of others and self) }\end{array}$ \\
\hline
\end{tabular}

When asked about their application of the knowledge domains at the different problem-solving stages, the respondents corroborated the connection between knowledge domains and experiential learning by indicating the knowledge type they used at the different nodes of the experiential learning problem-solving model. By identifying the knowledge domains applied at each problem-solving phase, participants verified the need for varied knowledge in a learning cycle and the connection between experiential learning and the knowledge domains. (Results not tabulated, but available upon request.)

\section{DISCUSSION}

This research set out to provide evidence through a case study that an interdisciplinary, experiential approach will help achieve the SDGs through a joint effort among universities, students, professors, an NGO, industry specialists, and the community members targeted for the SDG project. Concurrently, we assessed whether sustainability leadership and learning competencies could be developed within students while they worked on an SDG project through their capstone research course.

We provided evidence of progress toward the targeted SDGs based on an indicator for each goal. Although forming partnerships is set out by the 
United Nations as an SDG in itself, partnerships [30,31] are actually a means for achieving the other 16 SDGs. Success was possible because students independently selected parts of the project that they absorbed. Furthermore, they had the guidance of faculty members (as project supervisors), and industry partners (as subject matter experts) to recognize and fill the knowledge gaps. To guarantee that the project would remain sustainable by having beneficiary buy-in, a student participant conducted a Needs Assessment in collaboration with the University of Ouagadougou, Burkina Faso.

In the extant literature, experiential learning [9] and sustainability leadership competencies [28] are often discussed as complementary, especially through the work of Orr, Capra, and Sterling [7,30,31] and others who see the need for a strong conceptual background coupled with actionoriented community learning to achieve sustainability goals [32]. However, knowledge domains [6] have not been explicitly integrated in the discussion or tested empirically. In Figure 2, we illustrated how experiential learning and the knowledge domains can interact. We overlaid these two concepts with sustainability leadership competencies to illustrate how joining forces can support fulfillment of the SDGs, thereby contributing to the learning in all three of these streams. Frisk \& Larson [6] suggested that conventional learning methods will not necessarily lead to transformative action, which is required to fulfill the SDGs. To help initiate action toward the goals, our research illustrates that an opportunity provided to students through a capstone research course has the ability to motivate action conducive with a more sustainable future.

Even though the SEDV program is an inter-disciplinary degree program consisting of four academic disciplines and administered by Graduate Studies, without the capstone research course and the SDG project it likely would still suffer from fragmentation of knowledge acquired in its various disciplines. Furthermore, a capstone research project in itself does not guarantee a melding of experiential learning and the knowledge domains of declarative, procedural, effectiveness/impact, and social [6]. We have provided evidence through data gathered from student participants that experiential learning and the knowledge domains re-enforce each other through a partnership approach in a practical hands-on activity that helps to solve societal problems.

Regarding sustainable leadership, Wiek et al. [28] identified five competencies: systems thinking, strategic, anticipatory, normative, and interpersonal. Then, Savage et al. [29] developed an instrument to empirically measure Wiek et al.'s [28] competencies. Next, Meza Rios et al. [33] assessed the underlying structure of Savage et al.'s [29] measurement instrument through factor analysis and found that the competencies fall into three core organizing concepts: sustainability transition strategies, complex problem constellations, and sustainability visions, all necessary for transformative action in sustainability. "Sustainability education must 
be interdisciplinary, collaborative, experiential, and potentially transformative" [11] but students need to understand complex sustainability problems (conceptual problem-solving frameworks, holistic concepts, and systems thinking acquired in course work) to feel competent to handle sustainability problems and create visions for the future. Furthermore, sustainability transition strategies, developed from experiential hands-on learning, mediates the other two factors [33]. Sustainability transition strategies consist of applying strategic thinking by designing a plan and determining necessary resources to carry out the plan.

Meza Rios et al. [33] tested the model on high school students. Our work with university graduate students further confirms the necessity to couple concepts acquired in course work with action plans acquired through experiential learning to create a sustainable vision for the future [34]. However, unlike Meza Rios et al. [33], we did not statistically test the data. Rather survey questions and focus groups confirmed that the students' perceptions that they acquired strong competencies in the areas of systems thinking, strategic, anticipatory, and interpersonal. Although normative competencies were still fairly strong, they were the weakest.

A project participant, with an undergraduate degree in business administration, acknowledged the connection between learning from the course and applying the learning during the project to form his own selfdirected experience;

"For me personally, I relied a lot on my personal experiences but then also actually understanding how the [Power Hub] project worked on a technical level is something I gained from course. I didn't really know how solar panels worked before our program, but I could do financial modeling prior to the program."

The statement acknowledges not just a self-directed learning experience but also the application of the principles of experiential learning, coupled with conceptual knowledge, to achieve the SDGs: SDG7 (ensure access to affordable, reliable, sustainable and modern energy for all); SDG 8 (promote sustained, inclusive and sustainable economic growth, full and productive employment and decent work for all); SDG 9 (build resilient infrastructure, promote inclusive and sustainable industrialization and foster innovation). These goals were achieved by means of SDG17 (strengthen the means of implementation and revitalize the global partnership for sustainable development).

By understanding "on a technical level” how the Power Hub would function, the financial modeller produced a "Pro forma Power Usage/Demand (kWh)" that determined his financial/revenue model [35]. This financial model predicted a self-sustaining enterprise that would have revenue from the milling machines as the second largest income generator. Other student projects addressed needs assessment, supply and demand of power, and the design of the Power Hub. 


\section{CONCLUSIONS}

This case study involved a partnership among university professors and students, industry representatives, an NGO, and communities to achieve targeted SDG goals. This partnership occurred through a capstone research project in an interdisciplinary Master of Science program in Sustainable Energy Development (SEDV) with the objective of developing and implementing a solar Power Hub (Figure 11) in a community without energy. The location was Pâ Village in Burkina Faso. The partnership enabled the application of knowledge domains learned to a great extent in the conventional classroom setting of the SEDV program and applied in an experiential setting in the capstone research program, which also provided an opportunity to develop sustainability leadership competencies. Data gathered from the local community and the NGO that was primarily responsible for the Power Hub implementation provided evidence to the extent that the SDGs were achieved. The survey and focus group discussion provided evidence of the connectedness of the knowledge domains (declarative, procedural, effectiveness, and social) to the experiential learning problem-solving process and the opportunity to develop sustainability leadership competencies. Our work supports the necessity for an experiential learning setting to solidify learning in the knowledge domains and leadership competencies to ensure transformational action in sustainability.

Moreover, addressing SDGs needs a complex, multi-dimensional approach. For this reason, the United Nations suggests a partnership approach in its SDG 17 . This approach allows each partner, and especially the students in their research investigation, to specialize in their areas of expertise and to solve the problem step-by-step. Including the local stakeholders in the Needs Assessment ensures that the project will be relevant to their daily lives and hopefully have a lasting effect.

Although our sample was small (four SEDV students involved in the project), experiential learning is difficult to carry out in a setting with large class sizes. Our case study approach provides specific, detailed analysis that a generalizable study could not provide. Future research can determine if the findings in this research apply in different settings. The robustness of the experiential learning and knowledge type concept can be further tested with bigger sample sizes. However, the application of experiential learning techniques, the knowledge domains and the development of key sustainability leadership competencies have been shown to have had an influence in achieving the SDGs through a partnership arrangement. If adopted by others, the model and theories will facilitate the achievement of the SDGs by 2030. 
(A) The Power Hub Café (left) and Milling Area (right)

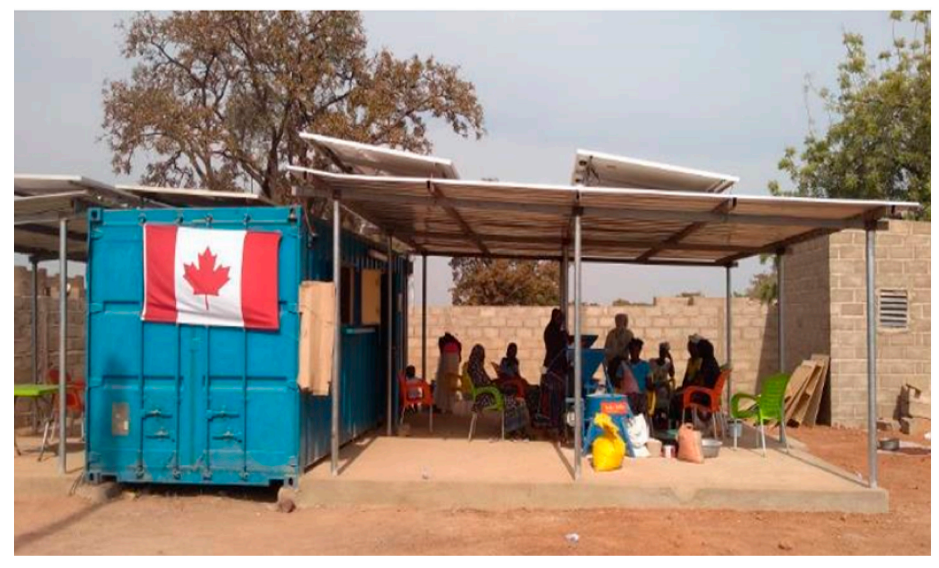

(B) A Milling Machine in use

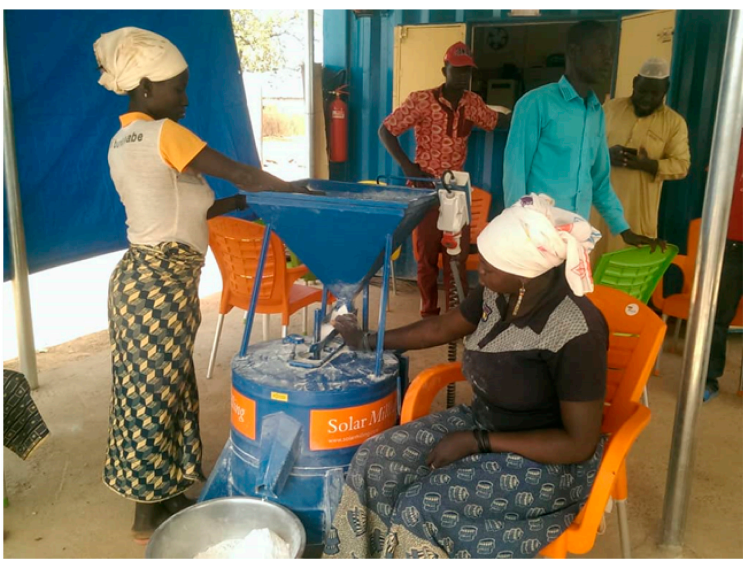

Figure 11. The Power Hub.

\section{AFTERMATH}

Approximately nine months after the Power Hub's launch, the Sougrinooma Women's Cooperative is now producing soap from shea butter and other local ingredients (Figure 12). The Cooperative has developed its own branding and packaging based on equipment supplied by TSO. The women have recently sold their first batch of production. The Power Hub is now also connected to the grid. New electric milling machines to be powered by the grid, along with those powered by solar, are expected to arrive shortly to help increase milling capacity, increase revenues, and maximize the probability of long-term financial sustainability for the Hub. The Power Hub is a work-in-progress and could be for some time, which is another real-life aspect of the project that enhances the experiential learning.

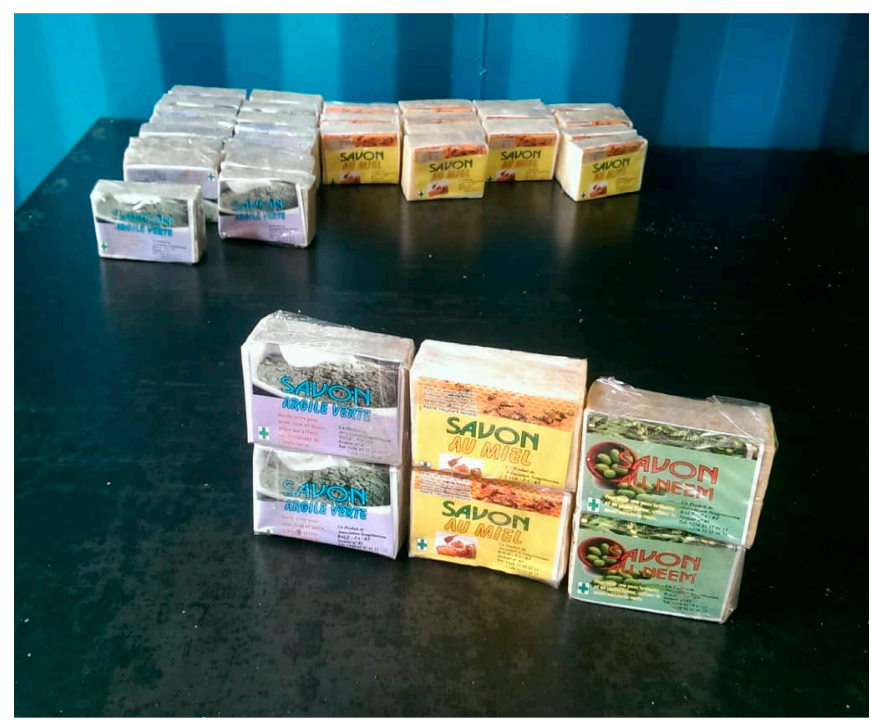

Figure 12. Soap from the Sourignooma Women’s Cooperative. 


\section{DATA AVAILABILITY}

Given the requirements of the Conjoint Faculties Research Ethics Board, the dataset of the study is not available.

\section{AUTHOR CONTRIBUTIONS}

All authors contributed equally to the project.

\section{CONFLICTS OF INTEREST}

The authors declare that there is no conflict of interest.

\section{FUNDING}

This article and research are funded by the Alberta CPA Managerial Accounting Fellowship.

\section{ACKNOWLEDGEMENTS}

We acknowledge the contributions of Andrea Cosgrove, Lucas Barr, Spencer Illingworth, Dr. David Wood, Dr. David Ince and Dr. Ed Nowicki.

\section{REFERENCES}

1. Willamo R, Helenuis L, Holmström C, Haapanen L, Sandström V, Huotari E, Kaarre K, Värreb U, et al. Learning how to understand complexity and deal with sustainability challenges - A framework for a comprehensive approach and its application in university education. Ecol Model. 2018;370;1-13.

2. Wals AEJ. Learning Our Way to Sustainability. J Educ Sustain Dev. 2011;5(2):177-86.

3. U.S. Environmental Protection Agency (U.S.E.P.A). Sustainability Primer. Washington, DC (US): US EPA; 2015. Available from: https://www.epa.gov/sites/production/files/2015-05/documents/sustainability primer v9.pdf. Accessed 2019 May 15.

4. Sgro J, Frayne B, McCormick C. Linking the Sustainable Development Goals through an Investigation of Urban Household Food Security in Southern Africa. J Sustain Res. 2019;1:e190004.

5. McArthur J, Muggah R. In an era of global uncertainty, the SDGs can be our guide? March 2019. Available from: https://www.weforum.org/agenda/2019/ 03/in-an-era-of-global-uncertainty-the-SDGs-can-be-our-guide/. Accessed 2019 Aug 7.

6. Frisk E, Larson KL. Educating for Sustainability: Competencies \& Practices for Transformative Action. J Sustain Educ. 2011;2:1-20.

7. Orr D. What is Education For? Six Myths about the Foundations of Modern Education and Six New Principles to Replace Them. Context. 1991;52.

8. Crow MM. None Dare Call It Hubris: The Limits of Knowledge. Issues Sci Tech. 2007;23:2.

9. Kolb AY, Kolb DA. Experiential Learning Theory: A Dynamic, Holistic Approach to Management Learning, Education and Development. In: Armstrong SJ, Fukami CV, editors. The SAGE Handbook of Management 
Learning, Education and Development. Thousand Oaks (US): SAGE Publications LTD; 2009. p. 42-68.

10. Brundiers K, Wiek A. Educating Students in Real-world Sustainability Research: Vision and Implementation. Innov High Educ. 2011;36:107-24.

11. Moore J. Is Higher Education Ready for Transformative Learning? A Question Explored in the Study of Sustainability. J Transform Educ. 2005;3:76-91.

12. Cranton P. Types of group learning. New Dir Adult Cont Educ. 1996;1996(71):25-32.

13. University of Calgary. Institutional Sustainability Strategy. 2018. Available from: http://ucalgary.ca/sustainability. Accessed 2019 Jun 12.

14. Ploum L, Blok V, Lans T, Omta O. Toward a Validated Competence Framework for Entrepreneurship. Organiz Environ. 2018;31(2):113-32.

15. The Strongest Oak Foundation. Solar Village of Future. Needs Assessment; Pâ Village Burkina Faso. Executive Summary. Calgary (Canada): The Strongest Oak Foundation; 2018.

16. Wills S. Power Hub Trip Update Jan16-25 2019 Final. Calgary (Canada): The Strongest Oak Foundation; 2019.

17. Wills S. Solar Village of The Future; The Power Hub. Calgary (Canada): The Strongest Oak Foundation; 2018.

18. The United Nations. Sustainable Development Goals. 2015. Available from: https://sustainabledevelopment.un.org/?menu=1300. Accessed 2019 May 15.

19. Mochizuki Y, Fadeeva Z. Competences for Sustainable Development and Sustainability Significance and Challenges for ESD. Int J Sustain High Educ. 2010;11:391-403.

20. Rieckmann M. Future-Oriented Higher Education: Which key Competencies Should be Fostered Through University Teaching and Learning? Futures. 2012;44:127-35.

21. Svanstrom M, Lozano-Garcia FJ, Rowe D. Learning outcomes for sustainable development in higher education. Int J Sustain High Educ. 2008;9:339-51.

22. Brundiers K, Wiek A, Redman CL. Real-world Learning Opportunities in Sustainability: From Classroom into the Real World. Int J Sustain High Educ. 2010;11(4):308-24.

23. Salgado FP, Abbott D, Wilson G. Dimensions of Professional Competencies for Interventions towards Sustainability. Sustain Sci. 2018;13:163-77.

24. Lambrechts WM, Van Petegem P. The Interrelations between Competencies for Sustainable Development and Research Competencies. Int J Sustain High Educ. 2016;17(6):776-95.

25. Redman E. Advancing educational pedagogy for sustainability: Developing and implementing programs to transform behaviors. Int J Environ Sci Educ. 2013;8:1-34.

26. Kaiser FG, Fuhrer U. Ecological Behavior's Dependency on Different Forms of Knowledge. Appl Psychol. 2003;52(4):598-613.

27. Gitsham M. Experiential learning for leadership and sustainability at IBM and HSBC. J Manag Dev. 2012;31(3):298-307. 
28. Wiek A, Withycombe L, Redman CL. Key Competencies in Sustainability: A Reference Framework for Academic Program Development. Sustain Sci. 2011;6(2):203-18.

29. Savage E, Tapics T, Evarts J, Wilson J, Tirone S. Experiential Learning for Sustainability Leadership in Higher Education. Int J Sustain High Educ. 2015;16(5):692-705.

30. Capra F. Sustainable Living, Ecological Literacy, and the Breath of Life. Can J Environ Educ. 2007;12:9-18.

31. Sterling S. Learning for Resilience, or the Resilient Learner? Towards a Necessary Reconcilliation in a Paradigm of Sustainable Education. Environ Educ Res. 2010;16(5/6):511-28.

32. Sipos Y, Battisti B, Grimm K. Achieving Transformative Sustainability Learning: Engaging Head, Hands and Heart. Int J Sustain High Educ. 2008;9:68-86.

33. Meza Rios MM, Herremans IM, Wallace JE, Althouse N, Lansdale D, Preusser M. Strengthening Sustainability Leadership Competencies Through University Internships. Int J Sustain High Educ. 2018;19:739-55.

34. Haigh MJ. Promoting Environmental Education for Sustainable Development: The Value of Links between Higher Education and Non-Governmental Organizations (NGOs). J Geogr High Educ. 2006;30:327-49.

35. Wills S. The Power Hub Business Plan. Calgary (Canada): The Strongest Oak Foundation; 2018.

How to cite this article:

Chineme A, Herremans IM, Wills S. Building Leadership Competencies for the SDGs through Community/University Experiential Learning. J Sustain Res. 2019;1:e190018. https://doi.org/10.20900/jsr20190018 